Richard A. Walker is Professor Emeritus of Geography at the University of California, Berkeley. He has written on a diverse range of topics in geography. His books include The Capitalist Imperative (1989), The New Social Economy (1992), The Conquest of Bread (2004), and The Country in the City (2007). He is currently working on books on the history and geography of the Bay Area and the political economy of California.

Suresh K. Lodha is Professor of Computer Science at the University of California, Santa Cruz. He is interested in curating, analyzing, and visualizing data for personal empowerment, public policy, and social change. He is a coauthor of The Atlas of Global Inequalities and has published more than 100 articles in journals and in conference proceedings. 


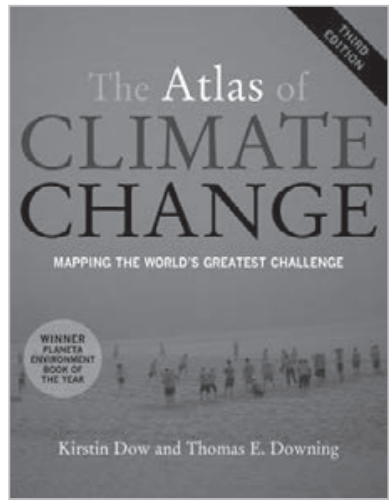

In the same series:

"Unique and uniquely beautiful. ... A single map here tells us more about the world today than a dozen abstracts or scholarly tomes." - Los Angeles Times

"A striking new approach to cartography. ... No one wishing to keep a grip on the reality of the world should be without these books." - International Herald Tribune
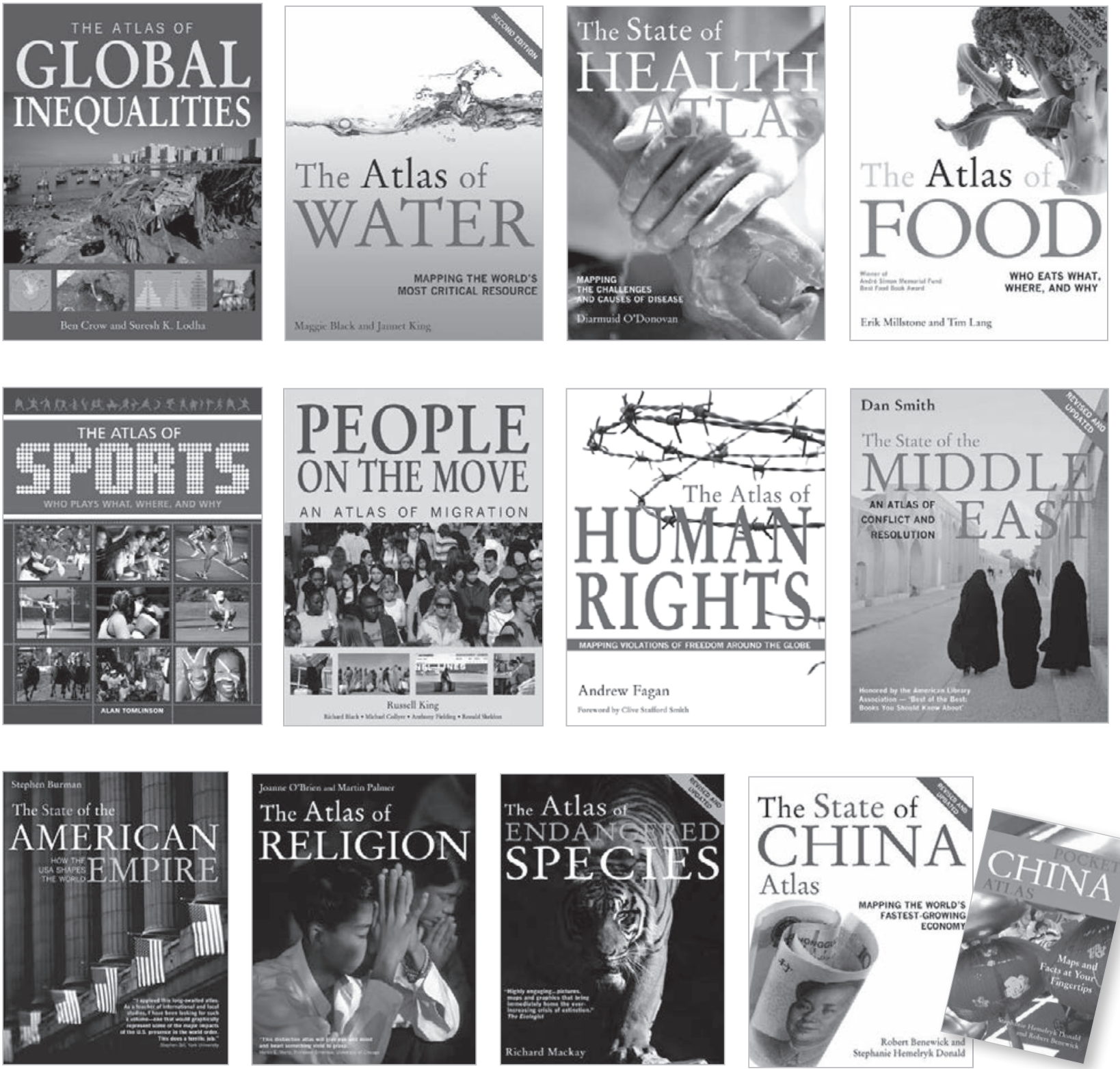


\section{The Atlas of}

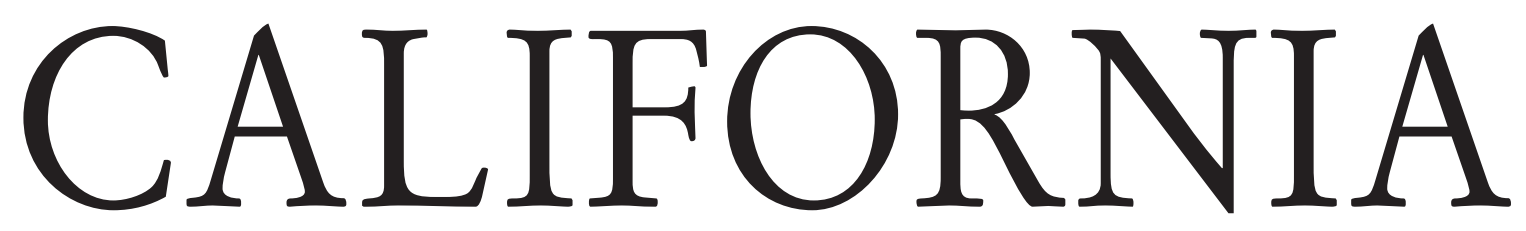

MAPPING THE CHALLENGES OF A NEW ERA

Richard A. Walker and Suresh K. Lodha

甲

UNIVERSITY OF CALIFORNIA PRESS

Berkeley Los Angeles 
University of California Press, one of the most distinguished university presses in the United States, enriches lives around the world by advancing scholarship in the humanities, social sciences, and natural sciences. Its activities are supported by the UC Press Foundation and by philanthropic contributions from individuals and institutions. For more information, visit www.ucpress.edu.

University of California Press

Berkeley and Los Angeles, California

Copyright (C) Myriad Editions Limited 2013

All rights reserved

The moral rights of the authors have been asserted

Library of Congress Control Number: 2013939442

ISBN: 978-0-520-27202-6 (pbk. : alk. paper)

ISBN (ebk): 978-0-520-96686-4

Produced for University of California Press by

Myriad Editions

Brighton, UK

www.MyriadEditions.com

Edited and coordinated by Jannet King

Designed by Isabelle Lewis

Additional design by Corinne Pearlman

Maps and graphics created by Isabelle Lewis

Printed on paper produced from sustainable sources.

Printed and bound in Hong Kong through Lion Production

under the supervision of Bob Cassels, The Hanway Press, London.

$\begin{array}{cccccccccc} & 17 & 16 & 15 & 14 & 13 & & \\ 10 & 9 & 8 & 7 & 6 & 5 & 4 & 3 & 2 & 1\end{array}$

This book is sold subject to the condition that it shall not by way of trade or otherwise, be lent, resold, hired out, or otherwise circulated without the publisher's prior consent in any form of binding or cover other than that in which it is published and without a similar condition including this condition being imposed on the subsequent purchaser. 